\title{
The Effect of Focus on Form on EFL Learners' Written Task Accuracy across Different Proficiency Levels
}

\author{
Asghar Salimi \\ Department of English, University of Maragheh, Maragheh, Iran \\ Alireza Bonyadi \\ Department of English, Uremia Branch, Islamic Azad University, Urmia, Iran \\ Atefeh Asghari \\ Department of English, Science and Research Islamic Azad University, West Azarbaijan, Iran
}

\begin{abstract}
One of the hotly debated areas of research in second language acquisition since 1990s has been pertained to the role of consciousness in learning second or foreign language. A review of the studies conducted on different aspects of consciousness in second language acquisition revealed there is a gap in the literature on the effect of focus on from instruction on L2 learners' oral or written task performance across different proficiency levels. Therefore, the present study set out to fill the existing gap in the literature and investigate the effects of form-focused instruction on $\mathrm{L2}$ learners' written task performance in terms of accuracy across two different proficiency levels (intermediate and advanced). To this end, sixty learners of English studying English in an institute were randomly chosen as the participants of the study. They were randomly divided into two groups of high and low proficiency levels. The two groups were also divided into two subgroups of with and without F-O-F. All groups were taught for 15 sessions. However, one subgroup of each group received form-focused instruction while the other two subgroups did not receive the treatment. A pictorial narrative task was employed as the post-test instrument to collect the written data. The collected written data were quantified and measured according to measures introduced by Ellis (2003). The findings of the study revealed that form-focused instruction had a significant effect on the accuracy of high proficient learners. The study carries some implications for second language acquisition researchers, language teachers, and syllabus and task designers.
\end{abstract}

Index Terms - focus on form, focus on forms, form-focused instruction, proficiency level, accuracy

\section{INTRODUCTION}

One of the most hotly debated issues in second language acquisition research over the past two decades pertains to the role of consciousness in second language learning. When second or foreign language learners perform on tasks, their performance in terms of three linguistic domains of fluency, accuracy, and complexity can be influenced by several factors like teacher experience, motivation of L2 learners, topic familiarity, generic features of the task, language proficiency of L2 learners, task structure, and the amount of noticing and attention to linguistic forms of the language (Rahimpour, 2008). Some SLA researchers argue that because focus on form makes SL development easier, special attention needs to be paid to form-focused instruction in the case of adult learners (Rahimpour and Salimi, 2010; Ellis, 2001, 2008, 2009; Gass, Mackey, and Pica, 1998; Long, 1996; Nassaji, 2009; Rahimpour et al, 2012). According to Ellis (2012), focus on form is based upon the claim that second language learning is enhanced if SL learners are provided with the opportunity to notice form while they are involved in meaning-focused language use. Also, Doughty (2001) argues that focus on form is distinguished from other approaches in that form-focused instruction engages SL learners shortly and probably at the same time paying attention to form, meaning, and use during a cognitive activity.

\section{A. Background of the Study}

Focus on form is defined by Long (1991) cited in Ellis (2012, p. 227) as "focus on form draws learners' attention to linguistic features as they arise incidentally in lessons whose focus is on meaning or communication". The claims made by Swain regarding noticing and its role in output hypothesis draw on the ideas proposed by Schmidt (1990) and Schmidt and Frota (1986) who claim that learners need to attend to a linguistic feature before acquiring it. Noticing can occur when second language learners are in the process of producing output realize that they do not know how to state their intended meaning (Schmidt, 1990). A particular feature of noticing is noticing the gap which takes place when learners receive corrective feedback and notice that it is different from their produced output (Swain, 1985). According to Mitchell and Myles (2004), the amount of attention that learners pay to form can affect the extent to which second 
language input produce SL intake, i.e. new language which has been adequately processed to be incorporated into the learners' developing language system.

One of the prominent scholars in the field of SLA whose works on noticing has been very influential is Schmidt. Schmidt (1994) distinguishes noticing from awareness in SLA. According to him, noticing refers to "the process of bringing some stimulus into focal attention, i.e. registering its simple occurrence, whether voluntarily or involuntarily" (p. 17). Awareness, as Schmidt argues, refers to our explicit knowledge of language or our "awareness of rules or generalization" (p. 18). Schmidt (1994) introduced the notion of noticing hypothesis and argued that noticing is the necessary and sufficient condition for the conversion of input into intake for learning. However, he modified his hypothesis and view later and argued that more noticing leads to more learning. Such changes in the theories of second language acquisition led to the introduction of the idea of "Focus on Form" (FOF) versus the traditional view of "Focus on Forms" (FOFs) toward teaching second/foreign languages. According to Long (1991), focus on forms refers to a traditional approach in which teacher presents learners with pre-selected and sequenced linguistic items. Also, as Ellis et al (2002) argues focus on forms refers to the selection of linguistic forms in advance which is based upon structural syllabus in which a main focus is on linguistic features of the language and the forms of the language are treated in systematic, intensive manner. Furthermore, Ellis (2012) argues that focus on form is an approach which involves "an effort to cause incidental acquisition via instruction by drawing learners' attention to linguistic features while they are engaged in communication" (p. 272). He also defines focus on forms as an approach in which "the chief goal is to help learners master the linguistic forms listed in the syllabus through making the linguistic goal of each lesson quite clear" (p. 272).

Besides, one of the many variables influencing L2 learners' language performance is proficiency level. It is one of the issues included in discussions of language learners' performance. In general, it is expected that advanced language learners would outperform learners with lower level of language proficiency level on a given language task. The idea behind this expectation is that because advanced language learners are expected to be competent in the language; hence, they are able to perform better. The studies which have studied the issue of second language proficiency have supported hypothesis that higher second language proficiency levels promote SL learners' awareness of linguistic features and the grammatical accuracy and indicate more correct sentence-level syntax (Savignon, 2005). These paradoxical findings in the current literature induce more studies on the degree to which second language learners' proficiency levels in SL can affect their language and task performance. These studies and their findings support the threshold hypothesis proposed by Cummins (1976) which was suggested to explain the results achieved in the previous studies which indicated bilingual children performing at lower levels than monolingual children.

\section{B. Statement of the Problem}

In current SLA research as well as language pedagogy several attempts have been made to investigate different aspects of and approaches to second language acquisition (Krashen and Terrel, 1983; Swain, 1985; Schmidt, 1990, 1994; Doughty, 1991; Spada, 1997; Long and Robinson, 1998; Doughty and Williams, 1998; White, 1998; Mackey et al, 2002; Ellis, 2001, 2002; Nassaji, 2007; Rahimpour, 2008, 2010; Salemi et al, 2012). These studies have reported different and significant findings with regard to the role of different approaches to second or foreign language teaching in L2 learners' language performance. Also, many researchers, in the past two decades, have been very interested in investigating the role of noticing and focus on form in second language acquisition (Swain, 1985; Schmidt, 1994; Harley, 1998; Doughty and Williams, 1998; Long and Robinson, 1998; Mackey et al, 2000; Ellis, 2002; Ellis et al, 2002; Leowen, 2003, 2005; Rahimpour, 2008, 2010; Salemi et.al, 2012). The findings of these studies have indicated that focus on form or form-focused instruction can have significant effects on L2 learners' language and task performance. Furthermore, in the literature of language teaching and learning, several studies have been conducted on the effects of L2 learners' proficiency level on their language learning and performance. However, there exists a gap in the literature on the effects of focus on form or form-focused instruction along with L2 learners' proficiency level on their written or oral task production. Therefore, the present study was an attempt to fill the existing gap in the literature and investigate the effects of focus on form and proficiency level on EFL learners' written performance in terms of accuracy.

\section{Significance of the Study}

Considering the plethora of studies conducted in the field of second language acquisition, it can be concluded that SLA is a burgeoning area of research. Although there have been many studies attempting to investigate different aspects of SLA, there are some kinds of gap in the literature with regard to some aspects of L2 learners' language acquisition and performance. The previous studies undertaken to investigate the effects of focus on form instruction on L2 learners' language learning and task performance have addressed different aspects of language learning; however, there have been few studies on the joint effects of focus on form instruction and L2 learners' proficiency level on their language learning and oral or written task production. The purpose and significance of the present study was to conduct a research on the joint effects of focus on form and language proficiency on L2 learners' written task accuracy and fill part of the existing gap in the literature. Moreover, the findings of the study have some implications for second language acquisition researchers, second language teachers in EFL contexts, and syllabus designers.

\section{LITERATURE REVIEW}




\section{A. Focus on Form Studies}

In a study on the effect of form-focused instruction on language learners' accuracy, Ellis (1984) reported that three hours of instruction directed at 'wh-' questions did not enable child ESL learners to produce the structure more accurately in a communicative game. Long (1988) looked into the effects of form-focused instruction on the processes, route and rate of L2 learning as well as the ultimate level of attainment. He found that the provision of formal instruction was beneficial in both cases and hypothesized that native-like levels of communicative competence may not be achievable through exposure alone. In a study Ellis (1993) studied the impact of explicit feedback on three groups of learners receiving explicit training on Walsh morphology in three different forms. The first group received random extensive instances of the language; the second group received only rule training, and the third a mixture of rules and instances. After the experiment, it was reported that the mixed group outperformed the other two groups in a wellformedness test. Carrol and Swain (1993) also conducted a study with one hundred Spanish adult ESL learners at intermediate level on dative verbs, investigating four types of feedbacks including metalinguistic, explicit, recast, and indirect metalinguistic feedback. The groups received two feedback sessions which were followed by a recall employing tests that production tasks were elicited after every feedback session. The findings of their study showed that all the groups performed better than the control group on both recall tasks. Group which received metalinguistic feedback outperformed the others. Spada and Lightbown (1993) report a study aimed at investigating the contribution of form-focused instruction and corrective feedback in the context of a communicative program to the development of interrogative constructions in the oral performance of ESL learners in Canada. Results seem to lend further support to the hypothesis that classroom instruction has a positive effect on learners' proficiency both in the short and the long (5 months) term. Nagata (1993) studied the effects of explicit corrective feedback on 32 junior students learning Japanese passive structures, verbal predicates, and particles. The first group received what was missing not expected, and the second group received the same type of feedback in addition to the metalinguistic explanations. The results of the study proved significant differences between the performances of two groups and group B outperformed group A on the particles, but not on the verbal predicates. Dekeyser $(1995)$ and Robinson $(1995,1996)$ reported upon the effects of implicit and explicit focus on form to see which type of corrective feedback is more effective. The results of the studies showed that explicit focus on form instruction led to more beneficial effects than did implicit learning. Long (1983) in an influential paper concluded that "there is considerable evidence to indicate that SL instruction does make a difference" (p.374). The results of eleven carried out studies proved that instruction was advantageous 1) for children as well as adults, 2) for both intermediate and advanced levels, and 3) acquisition rich and as well as acquisition poor environments. Ellis (2002) reviewed eight form-focused instruction studies. He concluded that form-focused instruction can contribute to the acquisition of second language. He argued that form-focused instruction involving extensive instruction directed at simple structures was more likely to succeed in developing implicit knowledge. Sanz (2003) studied the effects of explicit metalinguistic and implicit feedback on 28 Spanish freshmen on pronouns. The results of the study revealed improvement in their ability with no difference between the L2 groups. Leowen (2003) studied and examined the effectiveness of incidental focus on form in promoting SL development. Seventeen hours of naturally occurring, meaning-focused L2 lessons were observed in 12 different classes of young adults in New Zealand. The results of the study showed that second language learners were able to recall most of the linguistic information one day after the form-focused instruction and half of the time two weeks later. Han (2002) investigated a small-scale study of eight sessions studying the effect of recast on second language development on verb tense. One group received recast as the treatment on their erroneous utterances while the other received no recast. The result of the study showed that learners receiving recast led to more L2 learner awareness of target language forms and they had considerable improvement in the tense consisting of oral vs. written performance. Additionally, individualized attention, consistent focus, developmental readiness, and intensity were identified as necessary conditions to facilitate recast in the study. According to Izumi and Bigelow (2000), noticing led to learning as well, but this was facilitated by the type of task being used to produce noticing, since in order to encourage learners to notice the discrepancies between their own output and reformulated output, reformulation can be used to increase their awareness which in turn influences language development. Baraidi (2002) investigated the existence and short term use of recasts among English native speaker and Japanese non-native speaker students. The results of the experiment revealed that recasts do occur and that they are used in the short term. The findings of the study presents that recasts are obviously of some use to second language learners. White (1991) using an intact group design investigated the effect of formal instruction plus corrective feedback with three other groups who received no instruction. After the treatment the group with formal instruction showed more accuracy in written as well as oral test. Rahimpour and Maghsoudpour (2011) conducted a study to investigate teacherstudents' interactions in task-based and form-focused instruction. The participants of their study were two groups of intermediate English learners. They reported that form-focused instruction led to more teacher-student interaction than task-based approach. Abdolmanafi (2012) investigated the effects of form-focused instruction on the learning of relative clauses. To this end, intact university classes of English learners were divided into three groups receiving different forms of instruction. Accuracy of the target form was measured by two distinct tasks of sentence combining test and grammaticality judgment test. The results of the two tests show improvement of all three groups, the focus on form treatment group outperformed the other two on both tests, however. The findings of the study also suggest that learners' attention to the analysis of form in detail facilitates the learning of relative clauses. 
Rahimi and Riasati (2012) investigated the effect of explicit instruction of discourse markers on the quality of oral output. The participants of their study were forty Iranian EFL learners both male and female. The participants of the study were randomly assigned into two groups of twenty. The participants of the control group who attended the speaking course did not receive any explicit instruction on discourse markers, while the participants in the experimental group who attended the same course, were explicitly instructed on discourse markers. The experimental group received five sessions of explicit instruction on discourse markers, taking 20 minutes of the class time. Their findings indicated that the learners of the control group who received implicit instruction on discourse markers didn't employ discourse markers very often in their speech. While, the participants in the experimental group, who were explicitly instructed on discourse markers, employed discourse markers very often in their speech. They finally concluded that explicit teaching of discourse markers to learners in the experimental group was effective on the final oral production of language learners. Rahimpour, Salimi, and Farrokhi (2012a) investigated the effect of intensive and extensive focus on form on EFL learners' written accuracy. They randomly chose forty learners of English as the participants of their study. The participants of the study were randomly divided into two groups. They employed a pictorial narrative task as the means of data collection. They found that there were significant differences between the performances of the two groups in terms of accuracy. Rahimpour, Salimi, and Farrokhi (2012b) studied the effects of intensive and extensive form-focused instruction on L2 learners' oral task performance in terms of accuracy. They randomly chose forty learners of English as the participants of their study. The participants of the study were randomly divided into two groups. A pictorial narrative task was employed as the means of the data collection. The results of the study revealed no differences between the performances of two groups in terms of the accuracy in oral narrative task. However, the result of statistical analysis for the delayed post-test in focused intensive task was significant. Rahimpour, Salimi, and Farrokhi (2012c) studied the effects of planned and unplanned form-focused strategies on L2 learners' oral task performance in terms of accuracy. The participants of their study were sixty learners of English with pre-intermediate proficiency level. The participants were randomly assigned into three groups of planned, unplanned, and control. All the groups were taught for twenty sessions with different strategies. The findings of their study indicated that there were differences between the performances of the three groups in terms of accuracy of oral task production. Salemi et al (2012) studied the effects of explicit and implicit instruction and feedback on the development of Persian EFL learners' pragmatic competence in suggestion structures. The participants of their study included 100 EFL learners of intermediate language proficiency level who were randomly assigned into four experimental and one control groups. The experimental groups attended in two twenty-minute successive sessions. The participants in the study in different groups received the following instructions and feedback types. The first experimental group received explicit instruction and explicit feedbacks, the second experimental group received explicit instruction and implicit feedbacks and the other two experimental groups were instructed through implicit-explicit and implicit-implicit instruction and feedbacks, respectively. The findings of their study revealed that the learners participating in explicit-explicit method of instruction performed better than the learners of the other groups.

\section{B. Proficiency Level Studies}

Among several variables which can affect language learners' performance, the level of proficiency language has been one of the variables which have been considered in investigating learners' performance. It is expected that learners of high proficiency level would have better performance on language tasks. This is because high proficient learners are expected to have high competence in language; therefore, they can outperform other learners who are of low proficiency level. There have been some studies on the effects of proficiency level of language learners on their task performance (Carrell and Connor, 1991). Cumming (1989) investigated the effects of proficiency level on composition writing second language learners on different types of written task. In his study he employed different tasks namely, argument, summary and letter writing tasks. He found that proficiency level of language learners had significant effects on their written task performance. In another study, Carrell and Connor (1991) studied the effects of second language learners' proficiency level on written task performance. They employed narrative and argumentative writing tasks in their study. They also reported significant differences between language learners' proficiency level and their task production. According to Savignon (2005), the findings of studies conducted on language proficiency of learners and their language and task performance support the idea that second language learners of high proficiency levels have higher awareness of grammatical accuracy and demonstrate more accurate language performance. Some other studies (Cenoz and Valencia, 1994; Lasagabester, 2000; Sanz, 2000) investigated the effects of proficiency level o bilingual language learners on acquisition of third language, i.e. English. The findings of these studies indicated that learners with a good proficiency in two languages could learn English as a third language better than the others. The findings of these studies are in agreement with the threshold hypothesis (Cummins, 1976). Cummins (1976) offered the threshold hypothesis to explain the findings of the former studies which showed that bilingual language learners perform at lower levels than monolingual language learners. According to this hypothesis, bilinguals need to obtain a specific proficiency level before any cognitive benefits become evident. In fact, as it is stated in this hypothesis, there are some thresholds for bilingual second language learners. The first threshold is bilingual children who have low levels of competence in both languages, they are called limited bilinguals. This can lead to negative cognitive effects. The second threshold refers to bilinguals who have age-appropriate competence in one of the languages. In such bilingual statue one language will be somewhat weak and therefore the cognitive effects are neither positive nor negative. The third threshold is 
bilinguals who have age-appropriate competence in both languages. They are also known as proficient bilinguals. These bilingual language learners are likely to demonstrate positive cognitive effects (Cummins, 1976).

There are other studies which have examined the acquisition of specific features in a third language. Klein (1995) investigated monolingual and multilingual learners' acquisition of specific properties in both lexical learning and syntactic learning. She reported that the multilingual learners outperformed the monolinguals in acquiring specific features of the third language. Also, Fewell (2010) investigated language learning strategies and language proficiency in EFL Japanese university students. He compared differences in language learning strategies use and English language proficiency levels. He found that the selection of language learning strategies can be a crucial source of learners' success or failure in their language performance. Among several variables which can affect language learners' performance, the level of proficiency language has been one of the variables which have been considered in investigating learners' performance. It is expected that learners of high proficiency level would have better performance on language tasks. This is because high proficient learners are expected to have high competence in language; therefore, they can outperform other learners who are of low proficiency level. There have been some studies on the effects of proficiency level of language learners on their task performance (Cumming, 1989; Carrell and Connor, 1991). Cumming (1989) investigated the effects of proficiency level on composition writing second language learners on different types of written task. In his study he employed different tasks namely, argument, summary and letter writing tasks. He found that proficiency level of language learners had significant effects on their written task performance. In another study, Carrell and Connor (1991) studied the effects of second language learners' proficiency level on written task performance. They employed narrative and argumentative writing tasks in their study. They also reported significant differences between language learners' proficiency level and their task production. According to Savignon (2005), the findings of studies conducted on language proficiency of learners and their language and task performance support the idea that second language learners of high proficiency levels have higher awareness of grammatical accuracy and demonstrate more accurate language performance. Some other studies (Cenoz and Valencia, 1994; Lasagabester, 2000, Sanz, 200) investigated the effects of proficiency level o bilingual language learners on acquisition of third language, i.e. English. The findings of these studies indicated that learners with a good proficiency in two languages could learn English as a third language better than the others. The findings of these studies are in agreement with the threshold hypothesis (Cummins, 1976).

Cummins (1976) offered the threshold hypothesis to explain the findings of the former studies which showed that bilingual language learners perform at lower levels than monolingual language learners. According to this hypothesis, bilinguals need to obtain a specific proficiency level before any cognitive benefits become evident. In fact, as it is stated in this hypothesis, there are some thresholds for bilingual second language learners. The first threshold is bilingual children who have low levels of competence in both languages, they are called limited bilinguals. This can lead to negative cognitive effects. The second threshold refers to bilinguals who have age-appropriate competence in one of the languages. In such bilingual statue one language will be somewhat weak and therefore the cognitive effects are neither positive nor negative. The third threshold is bilinguals who have age-appropriate competence in both languages. They are also known as proficient bilinguals. These bilingual language learners are likely to demonstrate positive cognitive effects (Cummins, 1976). There are other studies which have examined the acquisition of specific features in a third language. Klein (1995) investigated monolingual and multilingual learners' acquisition of specific properties in both lexical learning and syntactic learning. She reported that the multilingual learners outperformed the monolinguals in acquiring specific features of the third language. Also, Fewell (2010) investigated language learning strategies and language proficiency in EFL Japanese university students. He compared differences in language learning strategies use and English language proficiency levels. He found that the selection of language learning strategies can be a crucial source of learners' success or failure in their language performance.

\section{RESEARCH QUESTION AND HYPOTHESIS}

The present study aimed at investigating the following research question and research hypotheses:

RQ: What are the effects of form-focused instruction on L2 learners' written task accuracy across different proficiency levels?

H0: There aren't any significant differences between form-focused instruction and L2 learners' written task performance in terms of accuracy across different proficiency levels

H1: High proficient L2 learners will outperform low proficient learners in terms of accuracy with form-focused instruction.

H2: Low proficient learners receiving form-focused instruction will outperform low proficient learners receiving without form focused instruction.

\section{Methodology}

\section{A. Participants}

The participants of the study were sixty learners of English who were randomly chosen as the participants of the study. They were studying English in Iran National Language Institute, Miandoab Branch. Thirty of them were 
intermediate and thirty were of advanced proficiency level. The participants of both intermediate and advanced level groups were divided into two subgroups of fifteen. One of the subgroups in each proficiency level received formfocused instruction while the other subgroup did not receive without form-focused instruction.

\section{B. Data Collection Instrument}

In order to collect the written data for the purpose of the study, a pictorial narrative task (Appendix 1) was employed as the means of the data collection. According to Skehan and Tavakoli (2005), a narrative task refers to the stories based upon an ordered set of picture prompts which are given to learners to elicit their task and language performance. It was tried to find the picture prompts which were clear and long enough and appropriate for the proficiency level of the learners of the study. At last, the task employed in the study had previously been used by other researchers (Rahimpour, Salimi, and Farrokhi, 2012) as a valid task.

\section{Procedure}

The main purpose of the study is to investigate the effect of form-focused instruction on L2 learners' written task performance in terms of accuracy across different proficiency levels. Sixty learners of English attending conversation courses in Iran National Language Institute, Miandoab Branch were randomly chosen as the participants of the study. Thirty of them were of intermediate and thirty were of advanced proficiency level. The participants of both intermediate and advanced level groups were divided into two subgroups of fifteen. One of the subgroups in each proficiency level received form-focused instruction while the other subgroup did not receive form focused instruction. The participants of the study attended in 15 sessions of instruction. Interchange 2 book was used as the instructional material for intermediate level participants. For participants of advanced level passages 1 book were used as the instructional material. The participants received treatment on the past tense reference in English which was the form under the focus of study. Two experimental groups in each proficiency level were instructed in accordance with the principles of formfocused instruction while the other two groups which were considered as the control groups of the study did not receive form-focused instruction. At the end of the experiment, the participants of all groups were given a post-test. The posttest involved a pictorial narrative task which made them compose an essay on the task given. That is, the participants were asked to narrate the story of the picture prompts. The collected written data was analyzed and quantified according to the measure for accuracy introduced by Ellis (2003) which was error-free T-units per T-units.

\section{Testing Instrument}

The collected written data from the participants was measured according to the element of written production of accuracy. The raw scores of the participants are presented in the appendix part of the thesis in table 1. The table involves the raw scores of the participants of both advanced and intermediate proficiency level groups with and without focus on form in terms of accuracy.

\section{Data Analysis AND Results}

Table 1shows the mean differences of accuracy of low proficient learners with and without form-focused instruction.

TABLE 1.

THE MEAN DIFFERENCES OF ACCURACY OF LOW PROFICIENT LEARNERS WITH AND WITHOUT FORM-FOCUSED INSTRUCTION

\begin{tabular}{llll}
\hline Proficiency level & N & Mean & Std. Deviation \\
\hline Intermediate +FOF & 15 & 0.34 & 0.043 \\
\hline Intermediate -FOF & 15 & 0.28 & 0.047 \\
\hline
\end{tabular}

According to the presented in table one, it was indicated that low proficient learners receiving form-focused instruction outperformed low proficient learners who did not receive form-focused instruction in terms of accuracy of written task performance. That is, low proficient learners with form-focused instruction produced more accurate language (0.34) than low proficient learners without form-focused instruction $(0.28)$.

Figure one vividly shows the mean differences of low proficient learners with and without form-focused instruction.

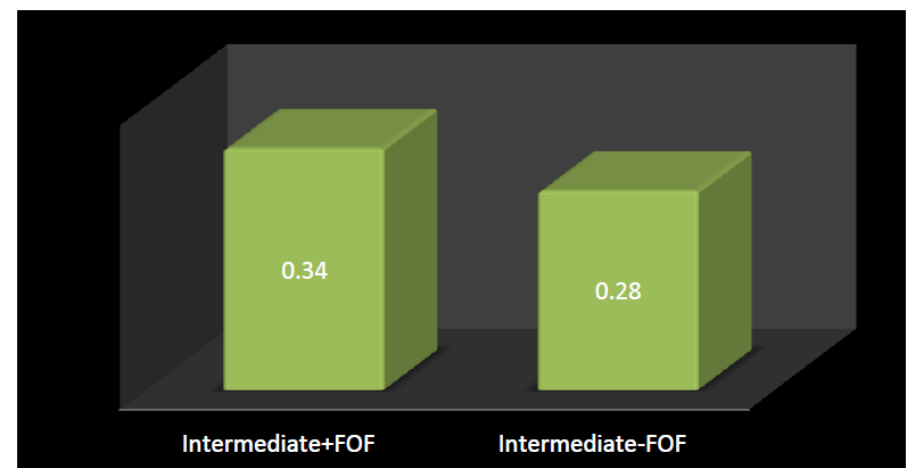

Figure 1. The mean differences of accuracy of intermediate learners with and without form-focused instruction 
Besides, the results of Independent Samples T-test for comparing the means of accuracy of low proficient learners with and without form-focused instruction are presented in the following table.

TABLE 2.

INDEPENDENT SAMPLES T-TEST FOR THE MEANS OF ACCURACY OF INTERMEDIATE LEARNERS WITH AND WITHOUT FORM-FOCUSED INSTRUCTION

\begin{tabular}{llllllll}
\hline & \multicolumn{2}{l}{$\begin{array}{l}\text { Levene's Test for } \\
\text { Equality of Variances }\end{array}$} & \multicolumn{2}{l}{ T-test Equality of Means } \\
\cline { 2 - 8 } & $\mathbf{F}$ & Sig. & $\mathbf{t}$ & df & $\begin{array}{l}\text { Sig (2- } \\
\text { tailed) }\end{array}$ & $\begin{array}{l}\text { Mean } \\
\text { Difference }\end{array}$ & $\begin{array}{l}\text { Std. Error } \\
\text { Difference }\end{array}$ \\
\hline Equal variances assumed & $\mathbf{0 . 0 3 7}$ & $\mathbf{0 . 8 5}$ & 3.37 & $\mathbf{2 8}$ & $\mathbf{0 . 0 0 2}$ & $\mathbf{0 . 0 5}$ & $\mathbf{0 . 0 1}$ \\
\hline $\begin{array}{l}\text { Equal variances not } \\
\text { assumed }\end{array}$ & & & 3.37 & $\mathbf{2 7 . 8 5}$ & $\mathbf{0 . 0 0 2}$ & $\mathbf{0 . 0 5}$ & $\mathbf{0 . 0 1}$ \\
\hline
\end{tabular}

Table 2 indicates the results of statistical analysis of Independent Samples T-test to test the third hypothesis. The results indicated that there was a trend toward significance between the performances of low proficient learners in terms of accuracy of written task performance with and without form-focused instruction.

Moreover, table three shows the results of Post Hoc Tukey test for the comparison of means of accuracy of low proficient learner with and without form-focused instruction.

TABLE 3.

POST HOC TUKEY TEST FOR THE MEANS OF ACCURACY OF LOW PROFICIENT LEARNERS WITH AND WITHOUT FORM-FOCUSED INSTRUCTION

\begin{tabular}{lllllll}
\hline & (J) Focus on & Mean Difference & & \multicolumn{2}{c}{ 95\% Confidence Interval } \\
\cline { 4 - 7 } (I) Focus on Form & Form & (I-J) & Std. Error & Sig. & Lower Bound & Upper Bound \\
\hline Int+FOF & Adv+FOF & $\mathbf{- 0 . 1 2 6 0}$ & $\mathbf{0 . 0 3}$ & $\mathbf{0 . 0 0 2}$ & $\mathbf{- 0 . 2 1}$ \\
\hline Adv-FOF & $\mathbf{- 0 . 0 3 2 0}$ & $\mathbf{0 . 0 3}$ & $\mathbf{0 . 7 6}$ & $\mathbf{- 0 . 1 1}$ \\
\hline & Int-FOF & $\mathbf{0 . 0 5 6 0}$ & $\mathbf{0 . 0 3}$ & $\mathbf{0 . 3 3}$ & $\mathbf{- 0 . 0 3}$ & $\mathbf{0 . 0 5}$ \\
\hline
\end{tabular}

The data presented in tables 2 and 3 indicated that there was a slight difference between the performances of low proficient learners in terms of accuracy of written task production with and without form-focused instruction. That is, low proficient learners receiving form-focused instruction outperformed low proficient learners who did not receive form-focused instruction in terms of accuracy of written task performance. Therefore, our null hypothesis was accepted and our third hypothesis claiming "low proficient learners receiving form-focused instruction will outperform low proficient learners receiving without form focused instruction" was rejected.

Table 4 shows the differences of the means of accuracy of high and low proficient learners with and without formfocused instruction.

TABLE 4.

THE MEAN DIFFERENCES OF ACCURACY OF HIGH AND LOW PROFICIENT LEARNERS WITH AND WITHOUT FORM-FOCUSED INSTRUCTION

\begin{tabular}{llll}
\hline Proficiency level & $\mathrm{N}$ & Mean & Std. Deviation \\
\hline Advanced +FOF & 15 & $\mathbf{0 . 4 6}$ & $\mathbf{0 . 1 2}$ \\
\hline Advanced -FOF & 15 & $\mathbf{0 . 3 7}$ & $\mathbf{0 . 1 0}$ \\
\hline Intermediate +FOF & 15 & $\mathbf{0 . 3 4}$ & $\mathbf{0 . 0 4 3}$ \\
\hline Intermediate -FOF & 15 & $\mathbf{0 . 2 8}$ & $\mathbf{0 . 0 4 7}$ \\
\hline
\end{tabular}

According to the data presented in table 4, it was revealed that high proficient learners receiving form-focused instruction produced the most accurate language (0.46) and the low proficient learners who did not receive formfocused instruction produced the least accurate language $(0.28)$.

Figure 2 clearly indicates the mean differences of accuracy of high and low proficient learners with and without form-focused instruction.

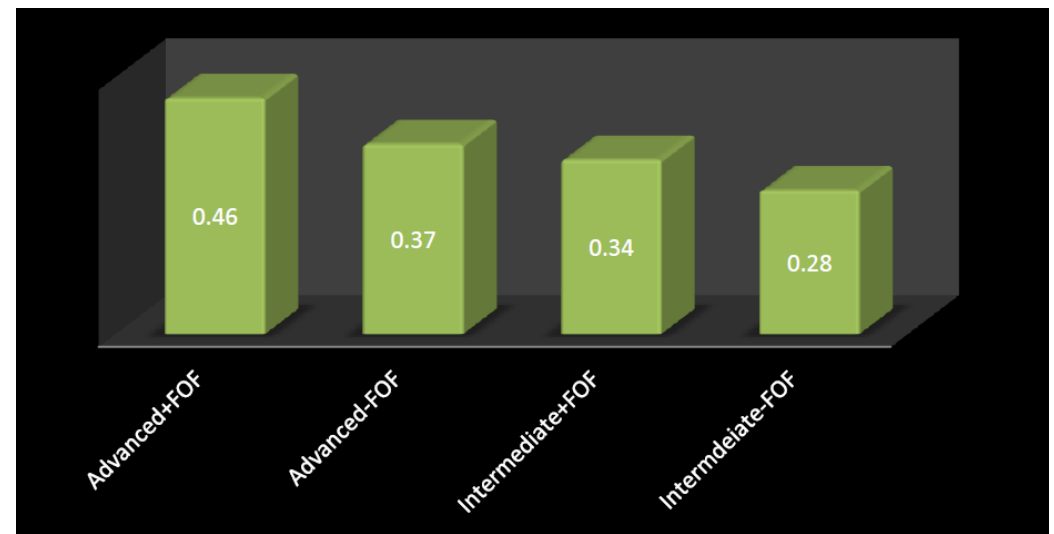

Figure 2. The mean differences of accuracy of advanced and intermediate learners with and without form-focused instruction. 
According to the above figure, it is evident that FOF effectiveness has a positive relationship with the proficiency of L2 learners. As proficiency develops, FOF becomes more effective.

\section{DISCUSSION}

Regarding the effects of form-focused instruction on accuracy of low proficient learners with and without formfocused instruction, the data provided in tables 4.8 and 4.9 and figure 4.3 revealed that there was no significant difference between the performances of low proficient learners in terms of accuracy of written task production. That is, the learners of low proficiency level group receiving form-focused instruction slightly outperformed the low proficient learners who did not receive form-focused instruction. Therefore, our null hypothesis was accepted.

The findings of the present study in terms of accuracy of the low proficient learners with and without form-focused instruction are in line with Ellis (1984), Sanz (2003), and Rahimpour et al (2012b). Sanz (2003) studied the effects of explicit metalinguistic and implicit feedback on 28 Spanish freshmen on pronouns. The results of the study revealed improvement in their ability with no difference between the L2 groups. Rahimpour et al (2012b) studied the effects of intensive and extensive form-focused instruction on L2 learners' oral task performance in terms of accuracy. The findings of the study indicated that there were no differences between the performances of the two groups in terms of the accuracy in oral narrative task. However, the result of statistical analysis for the delayed post-test in focused intensive task was significant.

However, the findings of the study in terms of accuracy of low proficient learners with and without form-focused instruction ran against the findings of Spada (1987), Long (1983), Leowen (2003), White (1991), Abdolmanafi (2012), Rahimi and Riasati (2012), Rahimpour et al (2012c), and Salemi et al (2012). White (1991) using an intact group design investigated the effect of formal instruction plus corrective feedback with three other groups who received no instruction. After the treatment the group with formal instruction showed more accuracy in written as well as oral test. Abdolmanafi (2012) investigated the effects of form-focused instruction on the learning of relative clauses. To this end, intact university classes of English learners were divided into three groups receiving different forms of instruction. Accuracy of the target form was measured by two distinct tasks of sentence combining test and grammaticality judgment test. The results of the two tests show improvement of all three groups, the focus on form treatment group outperformed the other two on both tests, however. This study also suggests that learners' attention to detailed analysis of form facilitates the learning of relative clauses in this context. Salemi et al (2012) studied the effects of explicit and implicit instruction and feedback on the development of Persian EFL learners' pragmatic competence in suggestion structures. The participants of their study included 100 EFL learners of intermediate language proficiency level who were randomly assigned into four experimental and one control groups. The experimental groups attended in two twenty-minute successive sessions. The participants in the study in different groups received the following instructions and feedback types. The first experimental group received explicit instruction and explicit feedbacks, the second experimental group received explicit instruction and implicit feedbacks and the other two experimental groups were instructed through implicit-explicit and implicit-implicit instruction and feedbacks, respectively. The findings of their study revealed that the learners participating in explicit-explicit method of instruction performed better than the learners of the other groups.

Considering the findings of the present study, it can be concluded that proficiency level and form-focused instruction can be influential on L2 learners' written task performance in terms of accuracy, especially when learners are of high proficiency level. Since, according to the results and findings of the study, high proficient learners pay more attention to the forms of language than learners which are of low proficiency level. This could be attributed to the nature of competition between form and meaning. At elementary or low proficiency levels it seems that the learners need to pay attention to both meaning and form simultaneously resulting the low rate of accuracy.

\section{Pedagogical Implications}

The present study and its findings have some implications for second language acquisition researchers, language teachers, and syllabus designers. For SLA researchers, the findings of the study can add to the current literature of SLA and provide some insights for other researchers in the field of second language acquisition. For language teachers, the findings of the present study can contribute them to provide learners of different proficiency level with different strategies of instruction in order to help them acquire the greatest amount of language proficiency and improve themselves. For syllabus designers, this study can provide them with some insights into how to design syllabus and tasks which are appropriate for language learners' proficiency level and allow teachers to use them creatively with different strategies of instruction.

\section{REFERENCES}

[1] Abdolmanafi, S. J. (2012). Effects of form-focused instruction on the learning of relative clauses. The Journal of Language and Linguistic Studies, 8 (1), 192-210.

[2] Braidi, S. (2002). Reexamining the role of recasts in native-speaker/non-native speaker interactions. Language Learning, 52, 142. 
[3] Carrell, P. L. and Connor, U. (1991). Reading and writing descriptive and persuasive texts. The Modern Language Journal, 75(3), 314-324.

[4] Carrol, S. and Swain, M. (1993). Explicit and implicit negative feedback: An empirical study of the learning of Linguistic generalization. Studies in Second Language Acquisition, 15, 357-360.

[5] Cenoz, J. and Valencia, J. F. (1994). Additive trilingualism: Evidence from the Basque country. Applied Psycholinguistics, 15, $195-207$.

[6] Cummins, J. (1976). The influence of bilingualism on cognitive growth: a synthesis of research findings and explanatory hypotheses. Working Papers on Bilingualism, 9, 1-43.

[7] Dekeyser, R. (1995). Learning L2 grammar rules: An experiment with a miniature Linguistic system. Studies in second Language Acquisition, 17, 379-410.

[8] Doughty, C. (1991). Second language instruction does make a difference: Evidence from an empirical study on SL relativization. Studies in Second Language Acquisition 13, 431-469.

[9] Doughty C (2001). Cognitive underpinning of focus on form. In. P. Robinson (Eds.). Cognition and Second Language Acquisition, (pp. 206-257). Cambridge: CUP.

[10] Doughty, C., and Williams, J. (Eds.). (1998). Focus on form in classroom second language acquisition. New York: Cambridge University Press.

[11] Ellis, N. (1993). Rules and instances in foreign language learning: Interactions of explicit and implicit knowledge. European Journal of Cognitive Psychology, 5, 289-318.

[12] Ellis, R. (1984). Can syntax be taught? A study of the effects of formal instruction on the acquisition of WH questions by children. Applied Linguistics, 5, 138-155.

[13] Ellis, R. (2001). Investigating form-focused instruction. In R. Ellis (Ed.), Form-focused instruction and second language learning (pp. 1-46). Malden, MA: Black well publishers.

[14] Ellis, R. (2002). Does form-focused instruction affect the acquisition of implicit knowledge? A review of the research. Studies in Second Language Acquisition 24, 223-236.

[15] Ellis, R. (2008). The study of second language acquisition. Oxford: Oxford University Press.

[16] Ellis, R. (2009). Task-based language teaching: Sorting out the misunderstandings. International Journal of Applied Linguistics, 19 (3), 229-246.

[17] Ellis, R. (2012). Language teaching research and language pedagogy. Wiley-Blackwell, Sussex.

[18] Ellis, R., Basturkmen, H., and Loewen, S. (2002). Doing focus on form. System, 30, 419-432.

[19] Fewell, N. (2010). Language learning strategies and language proficiency: An investigation of Japanese University students. TESOL Journal, 2, 159-174.

[20] Gass, S. M., Mackey, A., and pica, T. (1998). The role of input and interaction in second language acquisition: Introduction to the special issue. The Modern Language Journal, 82, 299-307.

[21] Han, Z. (2002). A study of the impact of recasts on tense consistency in L2 output. TESOL Quarterly, 36, 543-572.

[22] Harley, B. (1998). The role of focus-on-form tasks in promoting child L2 acquisition. In C. Doughty and J. Williams (Eds.), focus on form in classroom second language acquisition (pp. 156-174). New York: Cambridge University Press.

[23] Izumi, S., and Bigelow, M. (2000). Does output promote noticing and second language acquisition? TESOL Quarterly, 34, 239278.

[24] Klein, E. C. (1995). Second versus third language acquisition: Is there a difference? Language Learning, 45, 419 - 465.

[25] Krashen, S.D. and Terrell, T.D. (1983). The natural approach: Language acquisition in the classroom. Hayword, CA: Alemany Press.

[26] Lasagabaster, D. (2000). The effects of three bilingual education models on linguistic creativity. International Review of Applied Linguistics, 38, $213-228$.

[27] Loewen, S. (2003). The effectiveness of incidental focus on form in meaning focused ESL lessons. New Zealand Studies in Applied Linguistics, 9, 63-82.

[28] Loewen, S. (2005). Incidental focus on form and second language learning. Studies in Second Language Acquisition, 27, 361386

[29] Long, M. H. (1996). The role of linguistic environment in second language acquisition. In W.C.Ritchie and T.K.Bhatia (Eds.). Handbook of second language acquisition. (pp.413-463). San Diego; Academic Press.

[30] Long, M.H. and Robinson, P. (1998). "Focus on form: Theory, research, and practice", in focus on form in classroom Second Language Acquisition, C, Doughty and J. Williams, Eds. Cambridge: CUP, (pp. 15-42).

[31] Mackey, A., Philp, J., Egi, T., and Fujii, A. (2002). Individual differences in working memory, noticing of interactional feedback and L2 development. In P. Robinson (Ed.), Individual differences and instructed language learning (pp. 181-209). Amsterdam: John Benjamins.

[32] Mitchel, R. and Myles, F. (2004). Second Language Learning Theories. Oxford University Press.

[33] Nagata, N. (1993). Intelligent computer feedback for second language instruction. Modern Language Journal, 77, 330-339.

[34] Nassaji, H. (2007). Elicitation and reformulation and their relationship with learner repair in dyadic interaction. Language Learning, 57, 511-548.

[35] Nassaji, H. (2009). Interactional Feedback and L2 Learners' Development. International Conference, University of Yazd, Yazd, Iran.

[36] Mitchel, R. and Myles, F. (2004). Second Language Learning Theories. Oxford University Press.

[37] Rahimi, F and Riasati, M. J. (2012). The effect of explicit instruction of discourse markers on the quality of oral output. International Journal of Applied Linguistics and English Literature, 1 (1), 70-81.

[38] Rahimpour, M. (2008). Implementation of task-based approaches to language teaching. Pazhuhesh-e-Zabanha-ye Khareji Journal, University of Tehran, 41, 45-61.

[39] Rahimpour, M. (2010). Current trends on syllabus design in FL instruction. Procedia Social and Behavioral Sciences, 2, 166064. 
[40] Rahimpour M, Salimi A (2010). The impact of explicit instruction on foreign language learners' performance. Procedia- Social and Behavioral Sciences, 2, 1740-1746.

[41] Rahimpour M, Maghsoudpour M (2011). Teacher-students' interactions in task-based vs. form-focused instruction. World Journal of Education, 1 (1), 171-178.

[42] Rahimpour, M., Salimi, A., and Farrokhi, F. (2012a).The effect of intensive and extensive focus on form on EFL learners' written accuracy. Theory and Practice in Language Studies, 2 (11), 2277-2283.

[43] Rahimpour, M., Salimi, A., Farrokhi, F. (2012b). The impact of extensive and intensive focus on form strategies on EFL learners' oral accuracy. International Journal of Applied Linguistics \& English Literature, 1(6), 37-43.

[44] Rahimpour, M., Salimi, A., and Farrokhi, F. (2012c). The effect of planned vs. unplanned form-focused strategies on L2 learners' accuracy in oral task performance. Education Research Journal, 2(7), 247-252.

[45] Salemi, A., Rabiee, M., and Ketabi, S. (2012). The effects of explicit/implicit instruction and feedback on the development of Persian EFL learners' pragmatic competence in suggestion structures. Journal of Language Teaching and Research, 3(1), 188199.

[46] Sanz, C. (2000). 'Bilingual education enhances third language acquisition: Evidence from Catalonia. Psycholinguistics, 21,23 $-44$.

[47] Sanz, C. (2003). Computer delivered implicit vs. explicit feedback in processing instruction. In B. Van Patten (Ed.), Processing instruction: Theory, research, and commentary. Mahwah, NJ: Erlbaum.

[48] Savignon, S. J. (2005). Communicative Language Teaching: Strategies and Goals. In E. Hinkel (Ed.), Handbook of research in second language teaching and learning (pp. 635-651). Mahwah, NJ: Lawrence Erlbaum Associates.

[49] Schmidt, R. (1990). The role of consciousness in second language learning. Applied Linguistics, 11, 129-158.

[50] Schmidt, R. (1994). "Implicit Learning and the cognitive unconscious: of artificial grammars and SLA". In N.C. Ellis (Ed.), Implicit and explicit learning of Languages (pp. 165-209). San Diego, CA: Academic Press.

[51] Schmidt, R. , and Frota , S. ( 1986 ). Developing basic conversational ability in a second language. In R. Day (Ed.), Talking to learn (pp. 237 - 326). Rowley, MA: Newbury House .

[52] Schmidt, R. , and Frota , S. ( 1986 ). Developing basic conversational ability in a second language. In R. Day (Ed.), Talking to learn (pp. 237 - 326). Rowley, MA: Newbury House .

[53] Spada, N. (1997). Form-focused instruction and second language acquisition: A review of classroom and laboratory research. Language Teaching, 30, 73-87.

[54] Spada, N., and Lightbown, P. (1993). Instruction and the development of question in the L2 classroom. Studies in Second Language Acquisition, 15, 205-221.

[55] Swain, M. (1985). Communicative competence: Some roles of comprehensible input and comprehensible output in its development. In S. Gass and Madden (Eds.). Input in second Language acquisition (pp. 235-253). Rowley, MA: New bury House.

[56] White, R. (1988). The ELT Curriculum: Design, Innovation, and Management. Oxford: Basil Blackwell.

[57] White, L. (1991). Adverb placement in second language acquisition: Some effects of positive and negative evidence in the classroom. Second Language Research, 7, 133-161.

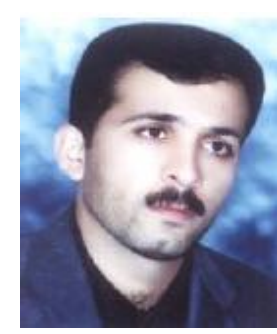

Asghar Salimi is a $\mathrm{PhD}$ in applied linguistics from University of Tabriz. He has been teaching English for over 10 years. He is currently a faculty member and assistant professor of applied linguistics at the University of Maragheh. He has presented and published more than twenty papers in different national and international conferences and journals in different countries. His main areas of interest are task-based learning and teaching, syllabus design, and Second Language Acquisition (SLA).

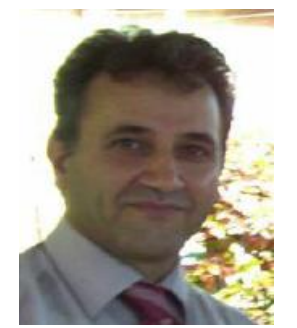

Alireza Bonyadi was born in 1964 in Urmia, Iran. In March, 2011, he earned his PhD in Teaching English as a Second Language from faculty of education university of Malaya, Kualalumpur, Malaysia. Presently he is the Head of English Department at Science and Research Branch of IAU, Azarbaijan-e-gharbi. He has published several research papers in scholastic journals some of them have been listed below: (2003) Translation: Back from Siberia. Translation Journal. Vol.7, No. 3, July. (2010) The Rhetorical properties of Schematic structures of Newspaper Editorials: A comparative study of English and Persian editorials. Discourse and Communication. (2011) Linguistic nature of presupposition in newspaper editorials. International Journal of Linguistics Vol. 3, No. 1.

His research interests include Discourse Analysis, Translation Studies and Language Teaching methodology. Dr. Bonyadi is presently an academic member of faculty of humanities in IAU, Urmia, Iran

Atefeh Asghari is an M.A in TEFL. She holds an M.A from Islamic Azad University, Urmia Branch. 